\title{
METHODS OF SAMPLING INVERTEBRATE DRIFT IN RUNNING WATER
}

\author{
by J. M. Elliotт.
}

GONTENTS

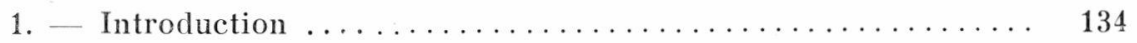

2. - Description of drift samplers ............... 134

2.1. - Samplers without flow-meters .......... 134

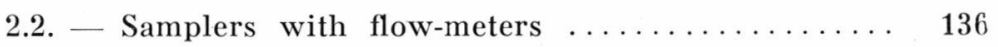

2.3. - Tube samplers and other samplers ....... 138

3. - Some problems associated with the sampling of invertebrate

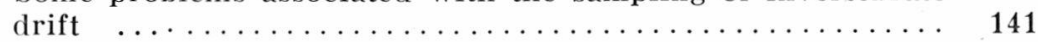

3.1. - The relationship between total discharge and invertebrate drift .................. 141

3.2. - The sampling efficiency of a drift sampler ... 143

3.3. - The study of the diel periodicity in invertebrate

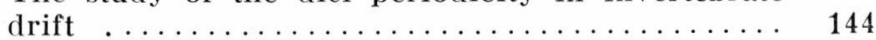

3.4. - Statistical aspects of sampling invertebrate drift 147

3.4.1. - Temporal variations in drift rate ..... 147

3.4.2. - Spatial variations in drift rate ........ 148

3.4.3. - Estimation of total numbers drifting downstream .................... 152

Summary - Résumé - Zusammenfassung .............. 155 


\section{INTRODUCTION}

The downstream drift of stream invertebrates is a normal feature of lotic systems. An excellent review by Waters $[1969\rfloor$ surveys most of the important literature on invertebrate drift [for further references, see Elliott 1967 a, Ulfstrand 1968, Bishop \& Hynes 1969]. As drift sampling is now an integral part of a study on stream invertebrates, it is important to consider the methods and problems of sampling invertebrate drift. The first part of the present paper reviews and criticises drift samplers, and the second part considers various problems associated with drift sampling.

\section{DESCRIPTION OF DRIFT SAMPIERS}

In early investigations, the drifting invertebrates were caught on a wire screen [DENDY 1944], or in a large net stretched across part or all of the stream width [NEEdham 1928, LenNon 1941, Müllek 1954]. Other methods of sampling invertebrate drift can be divided into three broad categories :

1. Samplers without flow-meters.

2. Samplers with flow-meters.

3. Tube samplers and other more complex samplers.

Each sampler is only described briefly in the following account, but references are given to the original descriptions.

\subsection{Samplers without flow-meters.}

A standard Surber-type bottom sampler [see Welch 1948] was used by some workers, e.g. TaNak $[1960]$. Waters $|1962|$ used Im-long lapered nets with a square mouth (Fig. 1A). The top edge of the net was above the water surface, and the bottom edge fitted close to a wooden board which was set in the stream bottom. Iron rods held the net in position and were driven through the board into the stream bed. Therefore the net filtered a column of water with a known cross-sectional area. This sampler and similar samplers have been used by several workers, e.g. Waters [1965, 1966|, BESCH |1966|, BAILEy [1966], DeNNERT et al. [1969] Bishop \& HyNes [1969].

A disadrantage of this type of drift sampler is that the net may become clogged with detritus and thus produce a backflow with a decrease in sampling efficiency. One solution to this problem 

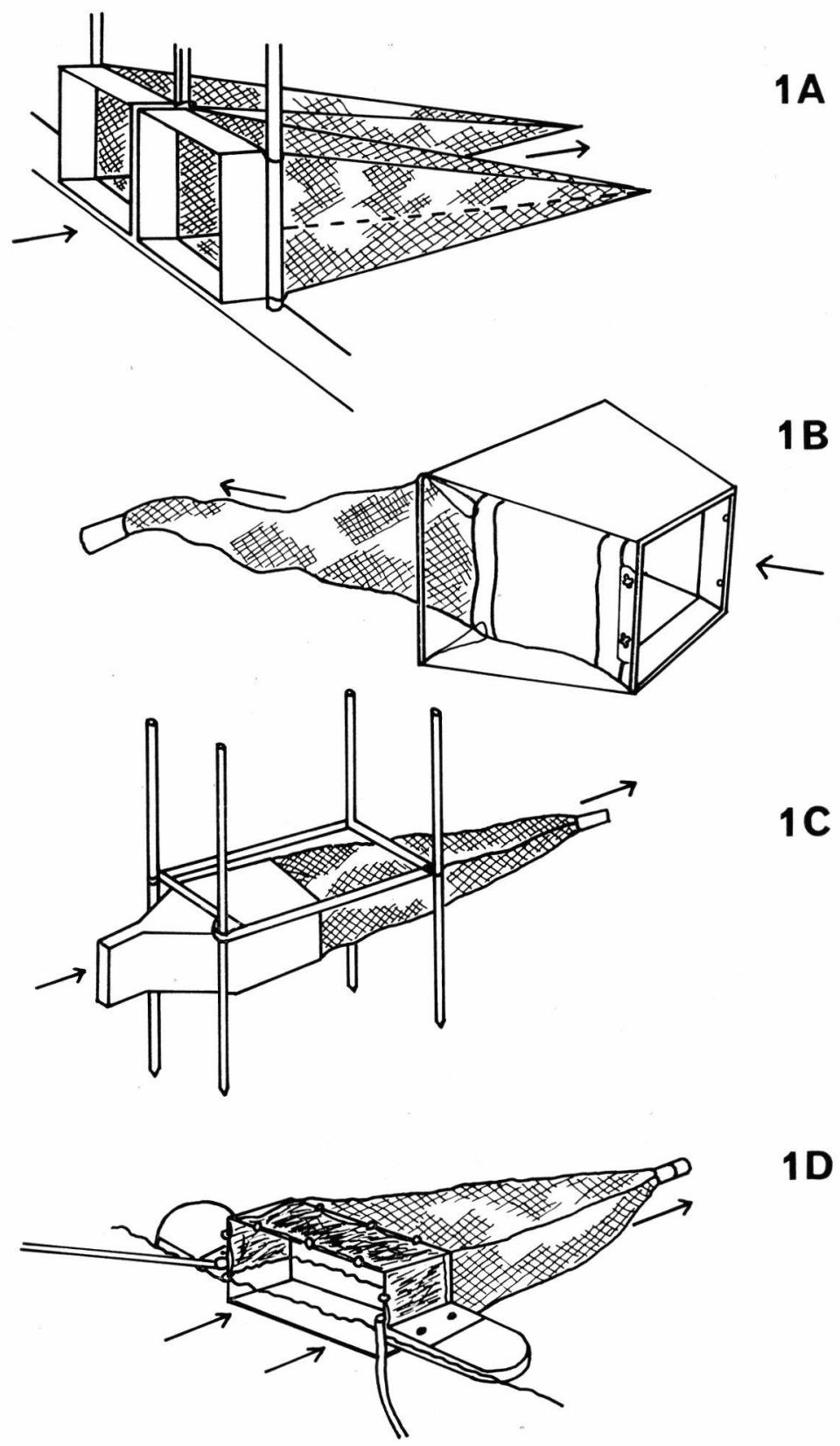

1D

FIG. 1. Samplers without flow-meters.

A. Fixed nets (after Waters 1962); B. Fixed net (after Anderson 1967); C. Cushing-Mundie sampler (after Cushing 1964, Mundie 1964); D. Surface net (after Elliot 1967a). Arrows indicate direction of flow. 
is to narrow the mouth of the sampler and retain a wider net immediately behind the mouth. The sampler used by ANDERson [1967] had a rectangular mouth leading to a slightly wider net with protective shields on the top and bottom (Fig. 1B). Cusning [1964] and Mundie [1964] designed similar drift samplers with narrow mouths (Fig. 1C). The sampler consisted of a metal box with a narrow inlet and wide outlet to which was attached the collecting net (c. $1 \mathrm{~m}$ long). Iron rods held the sampler in position and also served as legs on which the sampler could be raised or lowered. MUNDIE [1966] later mounted his sampler on floats to sample in deep water. This type of sampler was used by McLAY [1968] and HARDY [1968], who used glass-reinforced polyester resin (fibreglass) to build the funnel-shaped intake of the sampler. Hardy [1968] gives a very detailed description of this light-weight version of the Cushing-Mundie sampler.

Another disadvantage of most of these samplers is that the mouth of the net is close to the stream bottom. Non-drifting invertebrates can crawl directly into the nets and stone-cased larvae of Trichoptera may roll along the stream bed into the nets. Therefore a drift sampler should be clear of the bottom to ensure that only drifting animals enter the net. Elliot [1967 a] used surface nets which floated on the water and sampled to a depth of $7 \mathrm{~cm}$ from the water surface (Fig. 1D). Each net hooked onto a brass frame which had large wing-floats of polystyrene. Although this sampler did not have a narrow mouth, the effective mouth was a horizontal slit, $48 \mathrm{~cm}$ by $7 \mathrm{~cm}$. A polyethylene bottle at the apex of the net floated on the water surface and kept about half the net out of the water. If clogging occurred, more of the net sank below the surface and increased the filtration area of the sampler. Therefore the sampling efficiency of the net rarely decreased (see also 3.2.). In a sudden spate, the sampler rises with the water level and is thus saved from destruction. A valid criticism of this sampler is that it only catches surface drift. In shallow streams, the net is close to the bottom but for deeper water it is assumed that surface drift is typical of drift at other levels. This assumption is probably valid for benthic invertebrates but not terrestrial and emerging invertebrates in the drift [Waters 1965, Elliott 1967 a].

\subsection{Samplers with flow-meters.}

It is important to measure the volume of water passing through a drift sampler (see also 3.1.). Samplers described in 2.1. do not have flow-meters, but some workers measured water velocity at the mouth of the sampler. I have found that the small Ott current meter $\mathrm{C} 1$ is an ideal instrument for use with a surface net. 
$2 \mathrm{~A}$
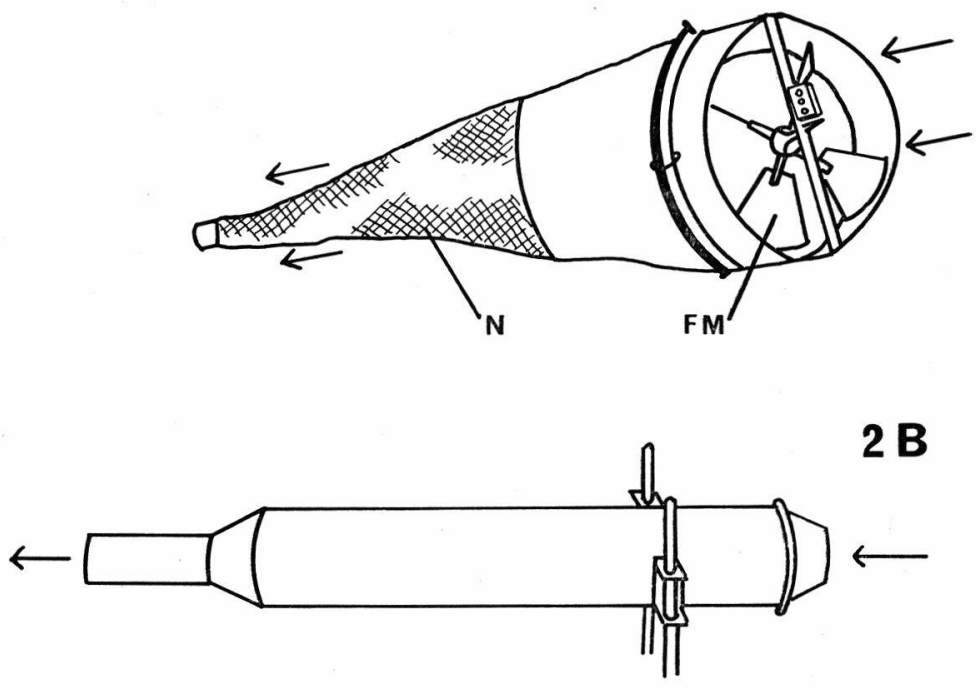

$2 \mathrm{C}$
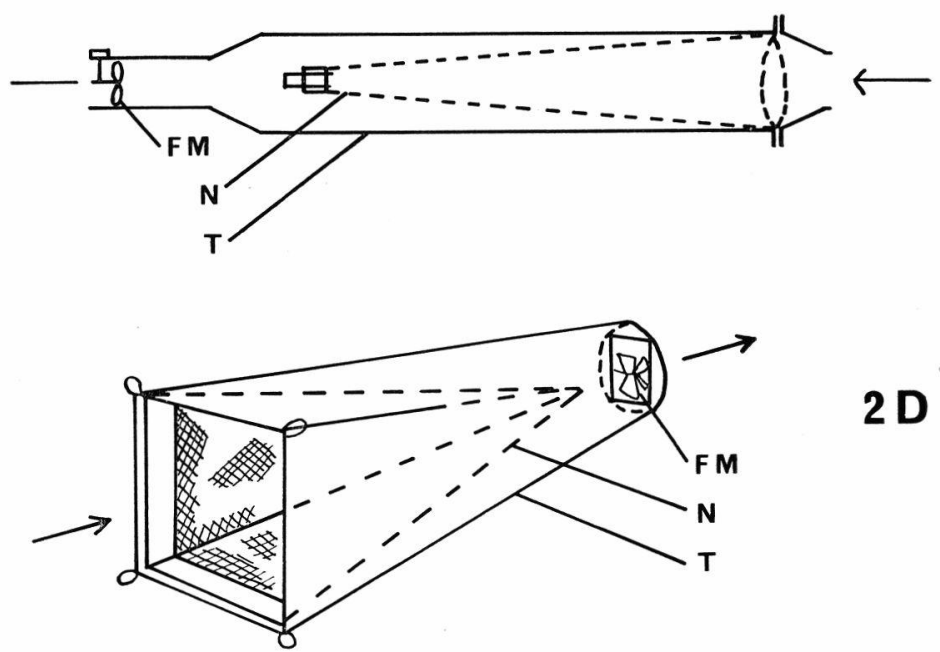

2 D

Fig. 2. Samplers with flow-meters.

A. Circular net (after MüLler 1958); B. Modified plankton sampler (after Ellotт 1967a); C. Modified plankton sampler in cross-section; D. Drift sampler (after Söpergen). Arrows indicate direction of flow. FM. flowmeter. N. net. T. metal tube. 
MüLler [1958] used a simple drift sampler with a recording propeller in the circular mouth of the net (Fig. 2A). Similar samplers were used by Ulfstrand [1968], and by Pearson \& Franklin [1968|. Lyakhov \& Zhidkov [1953] described a sampler which was used for short periods near the bottom of deep rivers. This robust apparatus had a flow-meter near the mouth of the sampler. Elliot $[1967$ a $]$ copied the design of a high-speed plankton sampler and enclosed the net in a metal cylinder which was held parallel to the stream bottom by iron rods (Fig. 2B). The net was held in place by a detachable cone which narrowed the mouth of the sampler and thus prevented rapid clogging of the net. A flow-meter was not placed in the mouth of the net as this may cause turbulence and the destruction of animals entering the net. Instead, the flow-meter was fixed in the rear end of the sampler and recorded the volume of water passing through the net (Fig. 2C). SöDERGREN (in litt.) uses a similar sampler which is of simpler design (Fig. 2D).

One disadvantage of these samplers is that they do not catch terrestrial invertebrates which are most numerous in the surface drift. This loss is not very important in studies on stream invertebrates, but may be a serious error in work on production or on the sources of available fish food. Surface nets [MUNDIE 1966, Elliott 1967 a] should be used in these investigations.

\subsection{Tube samplers and other samplers.}

The problem of clogging and backflow is often solved by reducing the mouth of the sampler (Figs. 1B, 1C, 2B). Another solution is to pass a portion of the stream discharge through a tube which ends in the air above a filtering net or sieve.

A simple tube sampler was used by Kuвicek [1966] in shallow streams. The outlet end of the plastic tube (length $300 \mathrm{~cm}$, diameter $5 \mathrm{~cm}$ ) was above the water surface (Fig. 3A). This allowed the water to fall into a filtering nel supported by two prongs. Crise [1966] also used long flexible pipes (diameter $5 \mathrm{~cm}$ ) which acted as siphons and ended in filters suspended in the air (Fig. 3B). The pipe intakes (diameter $3.5 \mathrm{~cm}$ ) were sited close to the stream bottom above a weir, and the filters were below the weir. In the original sampler, the intakes were attached to a large concrete block on the stream bottom (Fig. 3B), whereas they were suspended from a raft in a deeper stream and sampled at a fixed distance from the water surface (CRISP, in litt.). Müller [1966] used a gravityfed tube to supply water to a sieve (diameter $30 \mathrm{~cm}$ ) which stood on the bottom of a small stream below a small waterfall (Fig. 3C). 

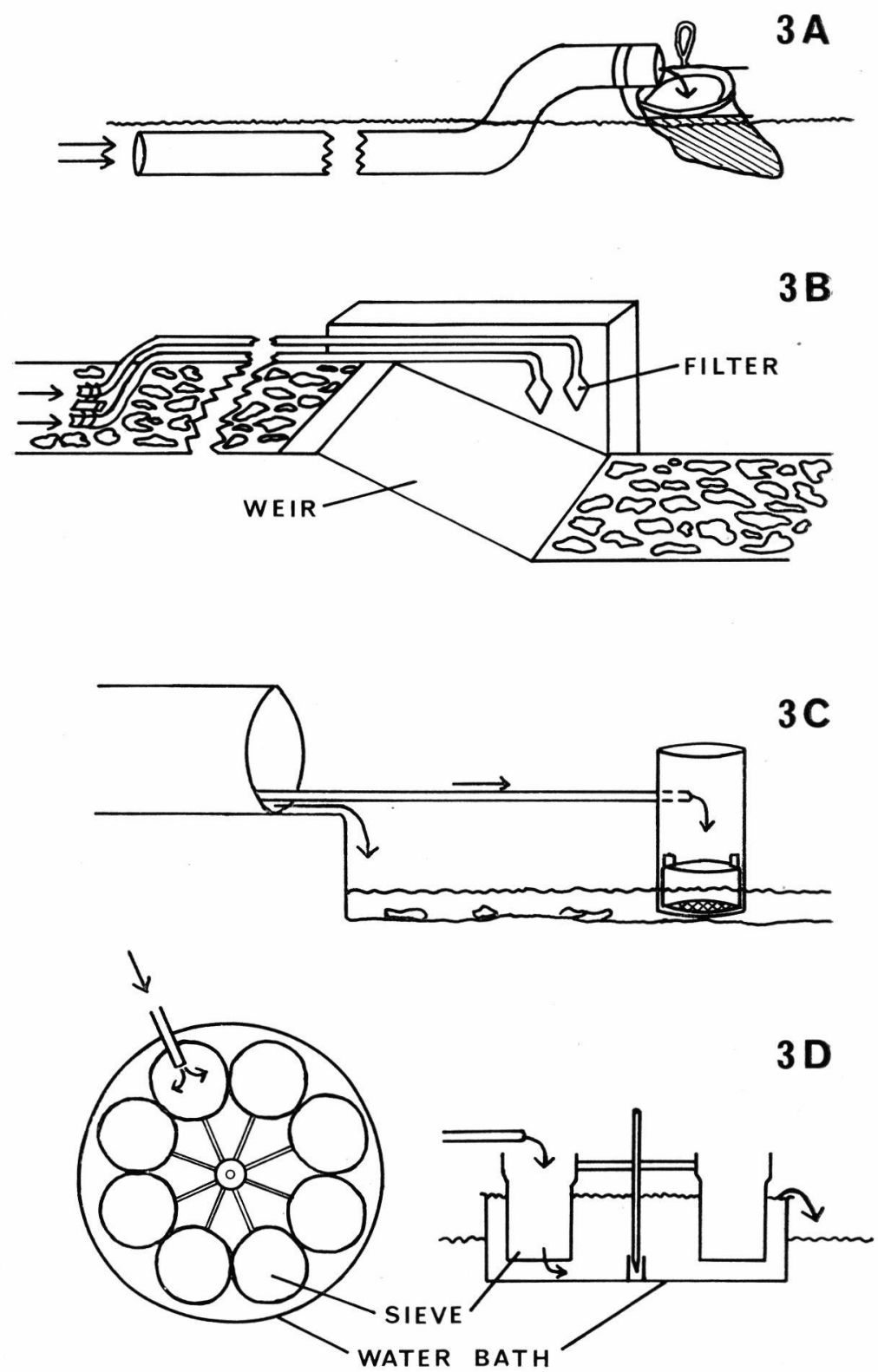

FIG. 3. Tube samplers.

A. After Kubicek (1966); B. After Crisp (1966); C. After Müller (1966); D. Automatic drift sampler. Left : from above. Right : from the side. Arrows indicate direction of flow. 
A disadvantage of tube samplers is that some invertebrates may cling to the inside of the tube and are not washed into the filter, e.g. larvae and pupae of Simulium. Therefore it is important to clean the inside of the tube at regular intervals. The volume of water passing through a tube sampler is easily measured at the outflow by recording the time taken to fill a bucket of known volume.

Although backflow may rarely occur in these tube samplers, the filters may still clog during periods of high discharge. CRISP [1966] used self-cleaning filters constructed of brass gauze. MüLler [1965, 1966] mounted eight sieves on a turntable (Fig. 3D) that rotated at standard time intervals (usually every $2 \mathrm{hr}$ ). The turntable was chain-driven by an electric motor powered by a battery. An alternative drive-mechanism is described by KURECK [1967]. MüLLER's elegant sampler requires a relatively stable water level and flow, but is the ideal sampler for studies on the diel periodicity in invertebrate drift (see 3.3.).

WoLF [1951] developed a trap which filtered all the water flowing down a stream. This large trap consisted of a fine-meshed screen set below a weir. The screen was set at a slight angle to the horizontal and filtered all the water falling over the weir. Fish and drifting invertebrates were washed off the screen into a collecting box with mesh sides. Although this trap was designed to catch fish, it should be an efficient drift sampler, especially in torrential streams subject to severe spates. One disadvantage is that the trap requires a water fall of at least 1 metre.

Pearson \& Kramer [1969] designed an ingenious drift sampler driven by a waterwheel (diameter $110 \mathrm{~cm}$, width $20 \mathrm{~cm}$ ). Small buckets 'were fixed on the perimeter of the wheel at a $40^{\circ}$ angle to the tangent (Fig. 4). As the wheel revolved, the buckets were filled underwater and emptied into a large trough. The trough was inclined at $10^{\circ}$ and emptied into a metal tube (diameter $9 \mathrm{~cm}$ ) to which was attached a nylon collecting net. The sampler was supported by a metal stand in shallow water and by floats in deep water. Catches with the sampler were compared with drift-net catches over $24 \mathrm{hr}$. The drift net (mouth $=30 \mathrm{~cm}$ diameter) filtered at the rate of $135 \mathrm{~m}^{3}$ water per hour, whereas the waterwheel sampler filtered $0.8 \mathrm{~m}^{3}$ water per hour. In spite of these differences, there was a good correlation between the catches of the two samplers. The chief advantages of the waterwheel sampler are that it does not easily clog, it samples a presiscly known volume of water, and it can sample for long periods. Disadvantages are that it samples near the surface and filters a small volume of water. Therefore invertebrates may be missed by the sampler when their density in the drift is low. 


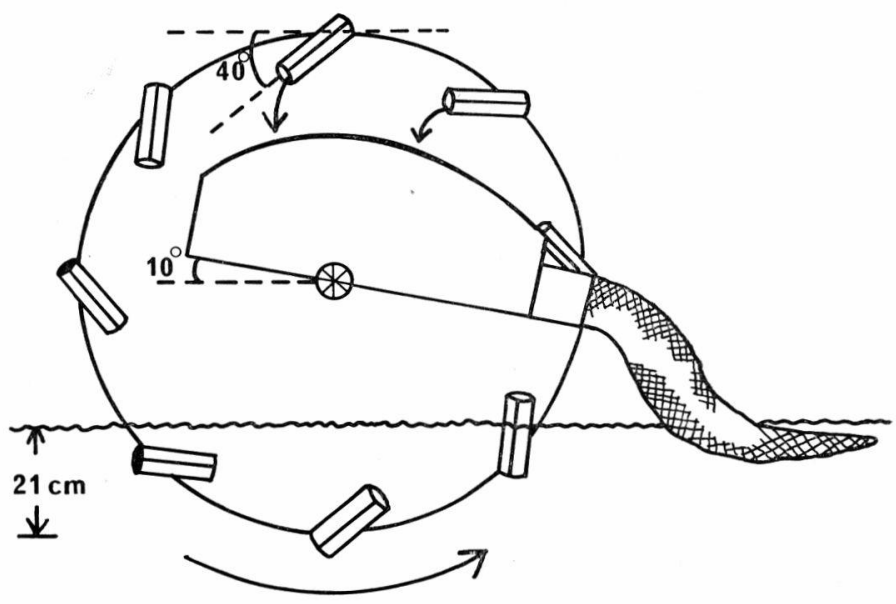

FIG. 4. Waterwheel drift sampler : lateral view.

\section{SOME PROBLEMS ASSOCIATED WITH THE SAMPLING OF INVERTEBRATE DRIFT}

\subsection{The relationship between total discharge and invertebrate drift.}

Total discharge is one of the chief factors affecting the magnitude of invertebrate drift. If the volume of water flowing through a drift sampler increases, the size of the catch increases [ELLIOTT 1967 a, 1967 b, 1968 a, Ulfstrand 1968, ANDERSon \& LEHMKuHL 1968, Bishop \& Hynes 1969]. Fig. 5 illustrates the correlation between total catch (numbers per 24hr) and the total volume of water sampled by a surface net $\left(\mathrm{m}^{3}\right.$ per $\left.24 \mathrm{hr}\right)$. The average relationship between the two variables is given by the regression line :

$$
\mathrm{Y}=0.32 \mathrm{X}-10.49
$$

where $\mathrm{Y}=$ numbers per $24 \mathrm{hr}, \mathrm{X}=\mathrm{m}^{3}$ per $24 \mathrm{hr}$. As some points lie far from the regression line, it is apparent that water volume was not the only factor affecting the total catch, i.e. drift density (numbers per unit volume of water) was not constant. The 54 points in Fig. 5 are drift samples taken at two sites over two years. Therefore departures from the regression line could be due to several factors, including differences between sites, seasonal changes in the density and growth of invertebrates in the benthos, and seasonal changes in the ratio of day to night. 


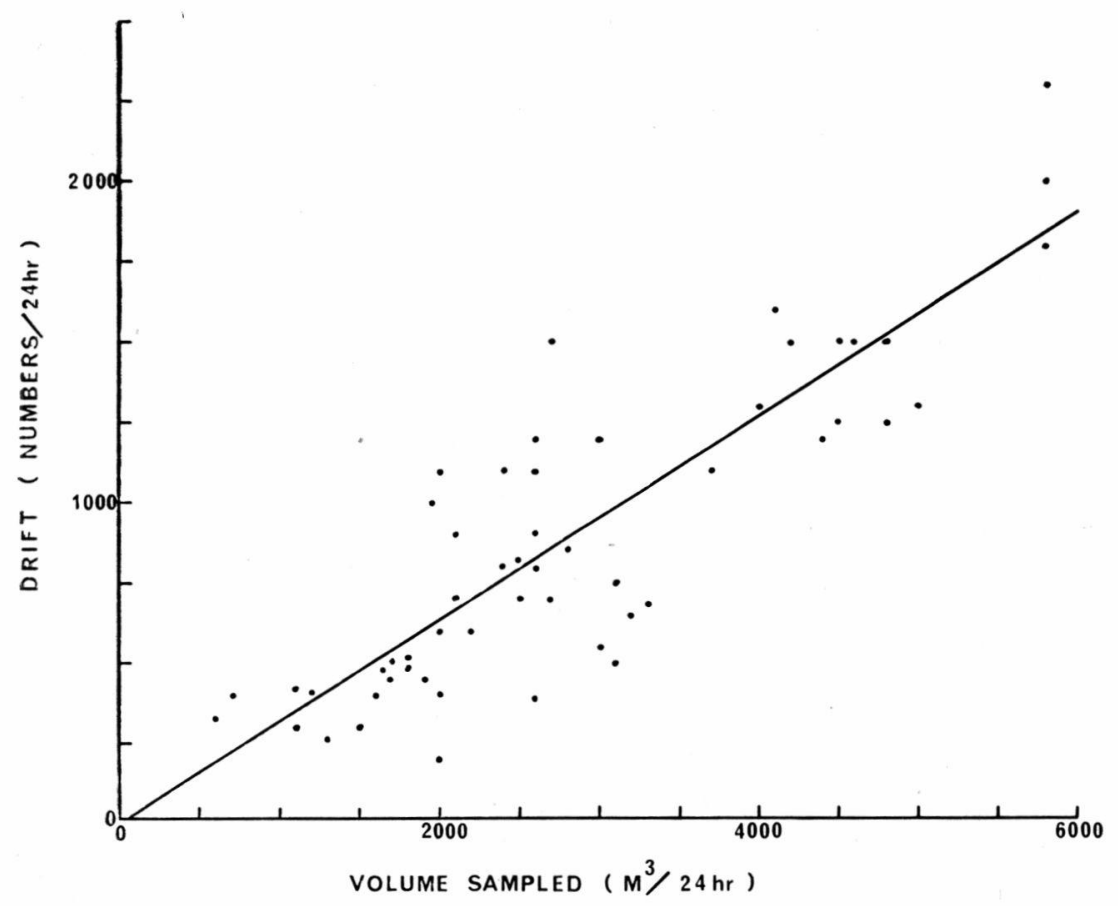

Fig. 5. An example of the relationship between invertebrate drift and the volume of water flowing through a drift sampler. Data from Walla Brook, Dartmoor (see ElliotT 1967a).

Ordinate : total number of invertebrates taken in a surface net over $24 \mathrm{hr}$. Abscissa : total volume of water sampled by the net $\left(\mathrm{m}^{3}\right.$ per $\left.24 \mathrm{hr}\right)$. A regression line is drawn on the figure.

It is important to distinguish between « drift density » (the number of invertebrates per unit volume of water) and " drift rate " (the number of invertebrates passing a sampling point in unit time). Both drift density and drift rate usually increase at night, and the daily drift rate for the whole cross-section of a stream is given by :

$$
\mathrm{N}=\mathrm{V}\left[\mathrm{T} . \mathrm{D}_{1}+(24-\mathrm{T}) \mathrm{D}_{2}\right]
$$

where $\mathrm{N}=$ total number of invertebrates drifting through the whole cross-section (across width of stream) in $24 \mathrm{hr}, \mathrm{V}=$ mean discharge in $\mathrm{m}^{3}$ per hour, $\mathrm{T}=$ length of night in hours, $\mathrm{D}_{1}=$ mean drift density at night (numbers per $\mathrm{m}^{3}$ ), $\mathrm{D}_{2}=$ mean drift density in the day.

$T, D_{1}$ and $D_{2}$ may be relatively constant for a short period of time, such as a week. Under such conditions, $\mathbf{N}$ is directly proportional to $\mathrm{V}$, and drift rate will increase with an increase in total discharge whilst drift density remains relatively constant. As ' $T$ 
varies throughout the year, it is possible for $\mathrm{N}$ to vary without any change in $\mathrm{V}, \mathrm{D}_{1}$ and $\mathrm{D}_{2}$.

The mean drift density in the day $\left(\mathrm{D}_{2}\right)$ is usually very low, and a close approximation of $\mathrm{N}$ is given by the product V.T.D. Drift. deusity is usually high at night, and the magnitude of $\mathrm{D}_{1}$ depends upon a complex of factors, including the density of invertebrates in the benthos [Waters 1961. Müllkr 1954, Ellot' 1967 a, Dimond 1967, Pearson \& Frankian 1968/, the stage in the life history of each species [Watwrs 1966, Müllek 1966, Elliott $1967 \mathrm{~b}, 1968 \mathrm{a}$, Anderson 1967 , the activity and behaviour of the invertebrates [CHASToN 1968, Ellotot $1968 \mathrm{~b}$ ], the water velocity to which the invertebrates are exposed, and competition between invertebrates for food and space / discussed in Elcort $1967 \mathrm{a}, \mathrm{b}$, BISHOP \& HYNES 1969 .

Although it is usually true that drift rate decreases with a decrease in total discharge, there may be an increase in drift rate when stream discharge is reduced to very low levels [ELLIotT 1967 a, Minshall \& Winger 1968, Waters 1969]. This increased drifting is probably an escape mechanism from streams that are drying up.

\subsection{The sampling efficiency of a drift sampler.}

All the samplers described in section 2 have a net, filter or sieve which may clog. The problem of clogging and backflow may be solved by the design of the sampler (Figs. 1B, 1C, 2B, 3A, 3B, 3C, 4), but the efficiency of most samplers will also depend upon the filtration area and mesh size of the collecting net.

WaTERs $|1969|$ compared different versions of his sampler (Fig. 1A) and found that backwash could be eliminated by varying mesh size, size of net mouth, length and shape of net, and sampling interval. One net (mouth width $15 \mathrm{~cm}$, length $200 \mathrm{~cm}$, mesh aperture $0.5 \mathrm{~mm}$ ) was used for $24 \mathrm{hr}$ wilhoul backwash, except under the most extreme conditions of debris. A cylindrical net was less liable to clog than a tapered net. Bishop \& HyNes [1969] used fixed nets (mouth 30 by $30 \mathrm{~cm}$, length $200 \mathrm{~cm}$, mesh aperture 0.167 by $0.56 \mathrm{~mm}$ ) which were sufficiently long to ensure that the standing wave caused by the resistance to flow was always more than $65 \mathrm{~cm}$ from the net mouth, even at the end of a $3 \mathrm{hr}$ sampling period. Cushing [1964] observed the flow of methylene blue dye through his sampler (Fig. 1C), and noles that the net (mesh aperture $1 \mathrm{~mm}$ ) sampled close to maximum efficiency.

The flow-meter in the rear of the modified plankton sampler (Fig. 2B, C) was used to measure the efficiency of the net (mouth diameter $15 \mathrm{~cm}$, length $68.5 \mathrm{~cm}$, mesh aperture $0.44 \mathrm{~mm}$ ). When the water velocity at the mouth of the sampler was less than 
$0.5 \mathrm{~m} / \mathrm{sec}$, the volume of water passing through the net $\mathrm{did}$ not decrease significantly over $12 \mathrm{hr}$. Sampling efficiency started to decrease after $12 \mathrm{hr}$ at $0.6 \mathrm{~m} / \mathrm{sec}, 10 \mathrm{hr}$ at $0.7 \mathrm{~m} / \mathrm{sec}, 6 \mathrm{hr}$ at $0.8 \mathrm{~m} /$ $\mathrm{sec}, 3 \mathrm{hr}$ at $0.9 \mathrm{~m} / \mathrm{sec}$, and $\frac{1}{2} \mathrm{hr}$ at $1 \mathrm{~m} / \mathrm{sec}$. These experiments were made in a Dartmoor stream [see Elliot $1967 \mathrm{a}, \mathrm{b}$ ] which becomes very turbid at higher water velocities $(>$ c. $0.7 \mathrm{~m} / \mathrm{sec})$. To test the sampling efficiency of a surface net (Fig. 1D) in the same stream, the whole net (effective mouth 48 by $7 \mathrm{~cm}$, length $100 \mathrm{~cm}$, mesh aperture $0.44 \mathrm{~mm}$ ) was enclosed in a polyethylene tube and a flow-meter was placed behind the net at the outlet of the tube. The sampling efficiency did not decrease significantly over $24 \mathrm{hr}$ when the water velocity at the net mouth was less than $0.6 \mathrm{~m} / \mathrm{sec}$. Sampling efficiency did decrease after $18 \mathrm{hr}$ at $0.7 \mathrm{~m} / \mathrm{sec}, 8 \mathrm{hr}$ at $0.8 \mathrm{~m} / \mathrm{sec}, 4 \mathrm{hr}$ at $0.9 \mathrm{~m} / \mathrm{sec}$, and $\frac{1}{2} \mathrm{hr}$ at $1 \mathrm{~m} / \mathrm{sec}$. These experiments were repeated in a small stony stream in the English Lake District and the surface net sampled close to maximum efficiency over $24 \mathrm{hr}$ at all velocities up to $0.8 \mathrm{~m} / \mathrm{sec}$, except in autumn when large numbers of deciduous leaves rapidly clogged the net.

Most workers have used a mesh aperture close to $0.5 \mathrm{~mm}$, e.g. Müller [1966], Elliott [1967 a, b], Waters [1969], Bishop \& HyNes [1969|. A few workers have used smaller mesh apertures of $0.333 \mathrm{~mm}$ [ANderson 1967], $0.263 \mathrm{~mm}$ [Minshall \& Winger 1968], $0.145 \mathrm{~mm}$ [Ulfstrand 1968]. The mesh aperture should be as large as possible to prevent clogging, and should still retain small invertebrates. This is easily tested empirically by placing a fine plankton net (mesh aperture $0.06 \mathrm{~mm}$ ) behind the drift net. I used this method to test the efficiency of a surface net and found that the mesh aperture of $0.44 \mathrm{~mm}$ retained small invertebrates, chiefly insects and Gammarus pulex $\mathbf{L}$.

There are few reports on the performance and sampling efficiency of drift samplers. The tests described in this section give some indication of the sampling efficiency of a few drift samplers. They also serve as a guide to methods of testing the sampling efficiency. Both the performance and sampling efficiency of a drift sampler will vary with local stream conditions, and should be thoroughly tested before the start of regular drift sampling.

\subsection{The study of the diel periodicity in invertebrate drift.}

A « diel periodicity» is defined as the recurrent temporal pattern of an activity with a 24 -hr period. Many workers have investigated the diel periodicity in the downstream drifting of aquatic invertebrates [see references in WATERs 1969]. The drifting of most species exhibits a nocturnal periodicity (i.e. drifting occurs chiefly at night), but there are a few exceptions, e.g. the diurnal periodicity shown by some species of Hydracarina and Trichoptera. 

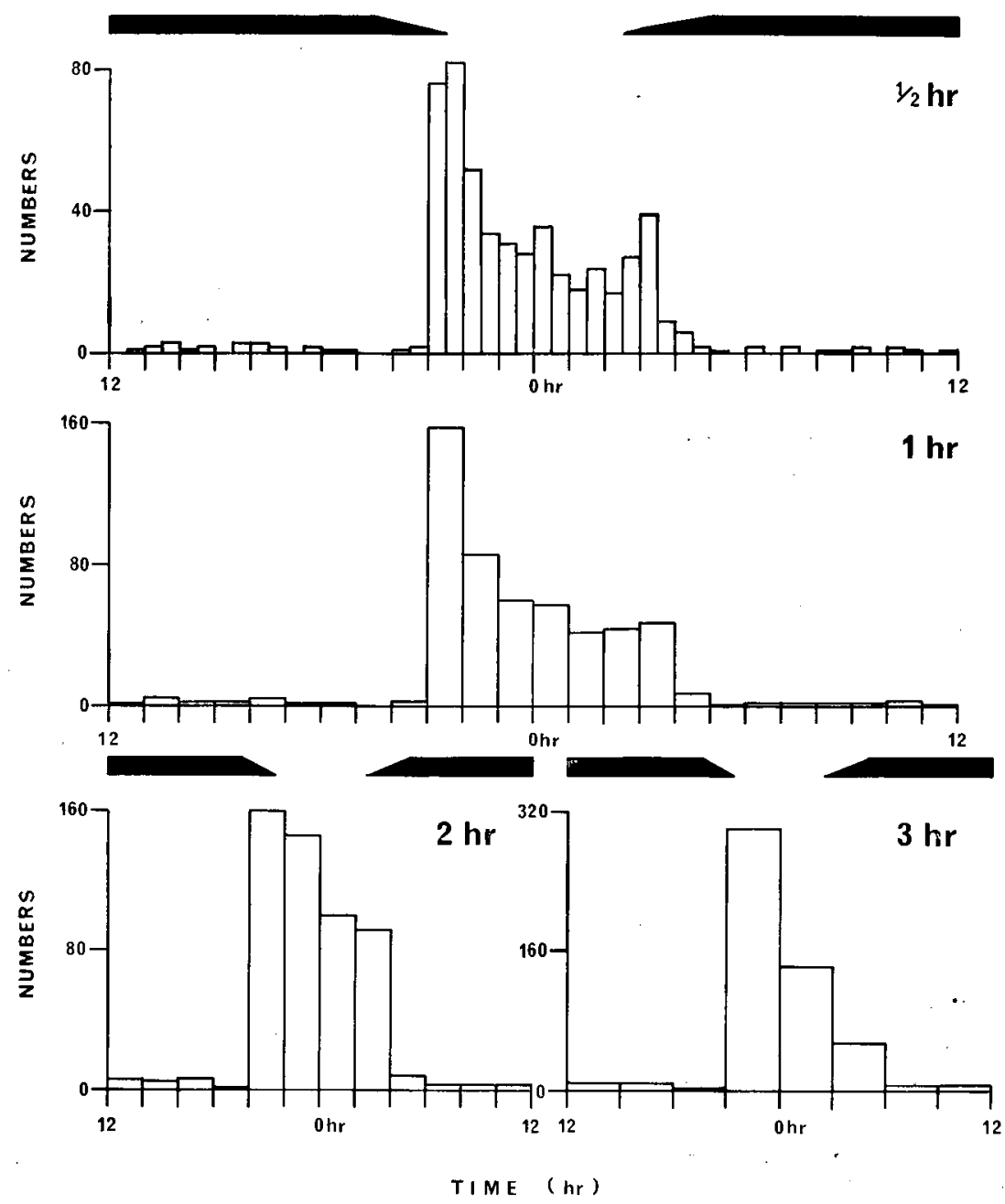

FIG. 6. The diel drift pattern of nymphs of Baëtis rhodani in July. Ordinate: number of nymphs taken in a drift sample over a period of either 1/2hr, $1 \mathrm{hr}, 2 \mathrm{hr}$, or $3 \mathrm{hr}$. Abscissa: time in hours with Ohr indicating midnight. The shaded portion at the top of each figure indicates the night period.

As the drift samples must be taken at frequent intervals of $3 \mathrm{hr}$ or less, a sampler should have a net, filter or sieve which can be quickly changed. MüLLER's (Fig. 3D) sampler has the advantage that the sieve is changed automatically at regular time intervals.

Some workers have assumed that the diel periodicity in drifting reflects the diel activity pattern of invertebrates in the benthos, 
i.e. peaks in the diel drift pattern indicate periods of maximum activity in the benthos. Although this assumption may be correct for some species, e.g. Gammarus pulex, it is supported by very little evidence. Ellot $\lceil\mathbf{1 9 6 8} \mathrm{b}\rceil$ compared the diel periodicities in the drifting and locomotory activity of mayfly nymphs (Ephemeroptera). Although both periodicities were nocturnal, they followed very different patterns during the night. Therefore the diel activity pattern of the nymphs in the benthos is only one of a complex of factors which determine the nocturnal periodicity in drifting. All of these factors are not known, but they include the number and spatial distribution of nymphs on the upper surface of stones at night, and the competition between nymphs for food and space. No other comparisons have been made between diel periodicities in drifting and locomotory activity. More work is clearly needed in this field.

There are definite peaks in the diel drift pattern of most species, and the principal peaks usually occur at night (nocturnal periodicity). The number and position of these peaks vary from species to species and also vary for the same species at different times of the year. Several workers have found that the nocturnal peaks occur at different times for the same species or for closely related species, e.g. Work on Baëtis spp. by Waters [1962], Müller [1963, 1966], Elliott $\lceil 1967 \mathrm{a}, 1968 \mathrm{~b} \mid$, Elliott and Minshall $[1968]$. One possible reason for this discrepancy is that different workers have used different sampling periods. Therefore it is important to understand the effect of different sampling periods on the diel drift pattern.

This effect is illustrated in Fig. 6, which shows the diel drift pattern of nymphs of Baëtis rhodani Pictet in July [for other examples, see Elı.oTt 1969]. The drift samples were taken over $12-\mathrm{hr}$ sampling periods to give 48 samples per day. There was a definite nocturnal periodicity in drifting with a primary peak at dusk, a secondary peak at dawn, and two minor peaks during the night (Fig. 6, $\frac{1}{2} \mathrm{hr}$ ). The catches for adjacent sampling periods were combined to give 24 sampling periods of $1 \mathrm{hr}$ each. This was repeated to give 12 samples per day (2_hr sampling periods) and 8 samples per day ( 3 -hr sampling periods). These larger catches would have been obtained if the nets had been emptied at either $1 \mathrm{hr}, 2 \mathrm{hr}$, or $3 \mathrm{hr}$ intervals. The marked effect of the longer sampling periods is seen in Fig. 6. Only the primary peak was clearly seen with all sampling periods, the secondary peak was just detected with a 1 -hr sampling period, and the other nocturnal peaks had apparently disappeared.

Therefore the use of different sampling periods can lead to widely divergent conclusions. In the example, four nocturnal peaks 
were detected with a $\frac{1}{2}-\mathrm{hr}$ sampling period, whereas only one peak was detected with a 3-hr period. Therefore differences between drift patterns must be interpreted with caution, and the shortest possible sampling period should be used in detailed studies of the diel periodicity in invertebrate drift.

\subsection{Statistical aspects of sampling invertebrate drift.}

The following statistical problems will be considered :

1. Temporal and spatial variations in drift rate.

2. Estimation of lotal numbers drifting downstream.

These problems are related and require similar statistical models.

\subsubsection{Temporal variations in drift rate.}

Although the drift rate of most species varies considerably over $24 \mathrm{hr}$, the catch for the same period of time on each day may show little variation over a few days. For example, the maximum catch per $\frac{1}{2} \mathrm{hr}$ sampling period is 82 in Fig. 6. The following catches were obtained for the same sampling period $(2130$ to $2200 \mathrm{hr})$ over 5 days :

$82,78,86,76,88$.

If the variation between these samples was due to random causes, the 5 samples should follow the well-known Poisson series (see Chapter 3.2.2. in Elliot 1970). Therefore the 5 samples were tested for randomness by the $\chi^{2}$ test for agreement with a Poisson series :

$$
\chi^{2}=\frac{(n-1) s^{2}}{\bar{x}}
$$

where $n=$ number of samples $=5, \bar{x}=$ arithmetic mean of sample, $s^{2}=$ sample variance.

$$
\bar{x}=\frac{\Sigma x}{n} \quad s^{2}=\frac{\Sigma(x-\bar{x})^{2}}{n-1}=\frac{\Sigma\left(x^{2}\right)-\bar{x} \Sigma x}{n-1}
$$

where $x$ is the number in each sample.

For the present example :

$$
\begin{gathered}
\bar{x}=\frac{410}{5}=82 \quad s^{2}=\frac{33724-82(410)}{5-1}=26 \\
\chi^{2}=\frac{4(26)}{82}=1.27
\end{gathered}
$$


This $\chi^{2}$ value is referred to a table of the percentage points of the $x^{2}$ distribution [e.g. Pearson \& Hartley 1966, Table 8]. Agreement with a Poisson series is accepted at the $95 \%$ probability level $(\mathrm{P}>0.05)$ if the $\chi^{2}$ value lies between the appropriate $5 \%$ significance levels for $v$ degrees of freedom $(v=n-1)$. Table I gives the $5 \%$ points for 3 to 10 degrees of freedom. As the $x^{2}$ value of 1.27 lies well within the $5 \%$ significance levels $(0.48$ and 11.14 for 4 degrees of freedom), agreement with a Poisson series is accepted $(\mathrm{P}>0.05)$. Therefore the variation in drift rate within the same $\frac{1}{2}$ hr period over 5 days was probably due to random causes. The arithmetic mean of the 5 samples $\overline{(x}=82)$ is the best estimate of drift rate for the particular sampling period.

Table 1. $5 \%$ significance levels for $\chi^{2}$ test for agreement with a Poisson series. Agreement is accepted $(\mathrm{P}>0.05)$ if $\chi^{2}$ value lies between lower and upper levels. Agreement is rejected $(\mathrm{P}<0.05)$ if $\chi^{2}$ value is less than lower level or greater than upper level. $v=$ number of degrees of freedom $=\mathbf{n}-1$

$\begin{array}{rcc}\mathrm{v} & \text { lower level } & \text { upper level } \\ 3 & 0.22 & 9.35 \\ 4 & 0.48 & 11.14 \\ 5 & 0.83 & 12.83 \\ 6 & 1.24 & 14.45 \\ 7 & 1.69 & 16.01 \\ 8 & 2.18 & 17.53 \\ 9 & 2.70 & 19.02 \\ 10 & 3.25 & 20.48\end{array}$

The same test was applied to the 5 samples for each $\frac{1}{2} \mathrm{hr}$ sampling period, and 48 means were thus obtained [Elliotr 1969]. As each mean was the arithmetic mean of 5 samples from a Poisson series, the standard test for a comparison of Poisson variables [see Chapter 7.1.2. in Elliotr 1970] can be used to compare the drift rate at different times of the day. The $\chi^{2}$ test can also be applied to total catches for the night, day, or $24 \mathrm{hr}$; when samples are taken over several days. When agreement with a Poisson series is accepted, means can be compared and tested for signicant differences. These comparisons can be extended to mean values for different months. If a significantly high value of $\chi^{2}$ is obtained, then agreement with a Poisson series is rejected and a significant change in drift rate must have occurred. This change invalidates comparisons between means with a Poisson series as the statistical model.

\subsubsection{Spatial variations in '? rift rate.}

If drifting invertebrates are randomly distributed in the water column and water velocity is fairly constant, then catches at different depths and at different points across the stream should follow 
a Poisson series. Unfortunately, water velocity usually varies with depth and a cross the width of the stream. This variation may significantly affect drift rate (catch per unit time), but will not affect drift density (catch per unit volume) when the drifting invertebrates are randomly distributed in the water.

Spatial variations in the drift rate of nymphs of Baetis rhodani were investigated in the Wilfin Beck, a small stony stream in the English Lake District. Both the sampling and statistical methods are now illustrated by examples.

In the study of the vertical distribution of drift rates, samples were taken at different depths by stacking five drift nets in the middle of the stream. As the water depth was $25 \mathrm{~cm}$ and the mouth of each net as $30 \mathrm{~cm}$ wide and $5 \mathrm{~cm}$ deep, all strata were sampled simultaneously from stream bottom to surface (each stratum was $5 \mathrm{~cm}$ deep). The following catches of $B$. rhodani were obtained during one night (sampling period $=8 \mathrm{hr}$ ).

Water depth

(cm from surface)

Numbers per net

$\begin{array}{rrrrr}0-5 & 5-10 & 10-15 & 15-20 & 20-25 \\ 128 & 132 & 114 & 103 & 98\end{array}$

Water velocity at net mouth (cm per sec)

$\begin{array}{llll}68 & 65 & 61 & 56\end{array}$

Water velocity decreased with depth and the drift rate was highest in the upper strata. The 5 samples were tested for randomness by the $\chi^{2}$ test for agreement with a Poisson series.

$$
\begin{gathered}
\vec{x}=115, s^{2}=223, n=5, v=4 \\
\chi^{2}=\frac{4(223)}{115}=7.76
\end{gathered}
$$

As this value lies within the $5 \%$ significance levels for 4 degrees of freedom (Table I), agreement with a Poisson series is accepted $(\mathrm{P}>0.05)$. Therefore there was no significant departure from a random distribution of drifting nymphs at different depths, in spite of the decrease in drift rate with depth.

In the study of the horizontal distribution of drift rates, samples were taken at night in seven nets which were evenly-spaced across the stream. Although water depth varied across the stream, each net sampled the whole column of water (width $12 \mathrm{~cm}$ ) from stream bottom to surface. The night catches in the first experiment are given in Table II, together with physical data. There was a close relationship between the size of a catch and the volume of water sampled by a net (see also 3.1 ). The 7 samples were tested for randomness by the $\chi^{2}$ test for agrecment with a Poisson series. 


$$
\begin{gathered}
\bar{x}=64.14, s^{2}=131.81, n=7, v=6 \\
\chi^{2}=\frac{6(131.81)}{64.14}=12.33
\end{gathered}
$$

As this value lies within the $5 \%$ significance levels for 6 degrees of freedom (Table $I$ ), agreement with a Poisson series is accepted $(P>0.05)$. Therefore there was no significant departure from a random distribution of drifting nymphs at different points across the stream, in spite of the variations in the volume of water sampled by each net.

Table II. Numbers of Baëtis rhodani taken in seven nets at night (sampling period was $8 \mathrm{hr}$ in experiment 1 and $6 \mathrm{hr}$ in experiment 2). Readings of water depth, mean water velocity at net mouth, and volume of water sampled during the night are given for each net. In experiment 2, the expected catches are given for the $\chi^{2}$ test for goodness-of-fit.

Net number

Water depth $(\mathrm{cm})$

Water velocity $(\mathrm{cm} / \mathrm{sec})$

Volume sampled $\left(\mathrm{m}^{3} / \mathrm{night}\right)$

Number per net

Net number

Water depth $(\mathrm{cm})$

Water velocity $(\mathrm{cm} / \mathrm{sec})$

Volume sampled ( $\left.\mathrm{m}^{3} / \mathrm{night}\right)$

Number per net

(observed catch)

Expected catch

\section{Experiment 1}

\begin{tabular}{rrrrrrr}
1 & \multicolumn{1}{c}{2} & \multicolumn{1}{c}{3} & \multicolumn{1}{c}{4} & \multicolumn{1}{c}{5} & \multicolumn{1}{c}{6} & \multicolumn{1}{c}{7} \\
$\mathbf{1 8}$ & $\mathbf{2 0}$ & $\mathbf{2 0}$ & $\mathbf{1 9}$ & $\mathbf{2 3}$ & $\mathbf{2 2}$ & $\mathbf{2 0}$ \\
$\mathbf{4 4}$ & $\mathbf{4 5}$ & $\mathbf{4 4}$ & $\mathbf{4 8}$ & $\mathbf{5 1}$ & $\mathbf{5 1}$ & $\mathbf{4 3}$ \\
$\mathbf{2 7 4}$ & $\mathbf{3 1 1}$ & $\mathbf{3 0 4}$ & $\mathbf{3 1 5}$ & $\mathbf{4 0 5}$ & $\mathbf{3 8 8}$ & $\mathbf{2 9 7}$ \\
$\mathbf{5 2}$ & $\mathbf{6 1}$ & $\mathbf{5 9}$ & $\mathbf{6 3}$ & $\mathbf{8 6}$ & $\mathbf{7 2}$ & $\mathbf{5 6}$
\end{tabular}

Experiment 2

\begin{tabular}{rlrrrrl}
1 & $\mathbf{2}$ & \multicolumn{1}{c}{$\mathbf{3}$} & \multicolumn{1}{c}{$\mathbf{4}$} & \multicolumn{1}{l}{$\mathbf{5}$} & \multicolumn{1}{c}{6} & $\mathbf{7}$ \\
$\mathbf{9}$ & $\mathbf{1 0}$ & $\mathbf{9}$ & $\mathbf{9}$ & $\mathbf{1 0}$ & $\mathbf{1 0}$ & $\mathbf{1 0}$ \\
$\mathbf{1 6}$ & $\mathbf{1 8}$ & $\mathbf{3 0}$ & $\mathbf{1 9}$ & $\mathbf{2 2}$ & $\mathbf{4 2}$ & $\mathbf{3 4}$ \\
$\mathbf{3 7}$ & $\mathbf{4 7}$ & $\mathbf{7 0}$ & $\mathbf{4 4}$ & $\mathbf{5 7}$ & $\mathbf{1 0 9}$ & $\mathbf{8 8}$ \\
$\mathbf{1 3}$ & $\mathbf{1 8}$ & $\mathbf{2 6}$ & $\mathbf{1 5}$ & $\mathbf{2 1}$ & $\mathbf{4 3}$ & $\mathbf{3 2}$
\end{tabular}

$\begin{array}{lllllll}13.75 & 17.47 & 26.02 & 16.35 & 21.19 & 40.51 & 32.71\end{array}$

The night calches in the second experiment (Table II) were also tested for randomness by the $\chi^{2}$ test.

$$
\begin{gathered}
\bar{x}=24.00, s^{2}=112.67, n=7, v=6 \\
\chi^{2}=\frac{6(112.67)}{24}=28.17
\end{gathered}
$$

As this value is greater than the upper significance level for 6 degrees of freedom (Table I), agreement with a Poisson series is rejected $(\mathrm{P}<0.05)$. Therefore there was a significant variation in drift rate at different points across the stream.

Drift rate (numbers drifting per unit time) often varies significantly with depth or across the stream $\left(x^{2}>\right.$ upper level in Table I). An obvious reason for this variation is that the drift rate reflects the volume of water sampled by a net. If this hypothesis is correct, then the catches in a series of nets should be proportio- 
nal to the volumes of water sampled by the nets. In experiment 2, 168 nymphs were caught in 7 nets which filtered $452 \mathrm{~m}^{3}$ of water. If the catches in the 7 nets were in the same proportions as the water volumes passing through them, then the expected calch for net $1=(37) 168 / 452=13.75$. Expected catches were calculated for each net and are compared with observed catches in Tables II. Agreement between the two sets of catches is tested by the $\chi^{2}$ lest for goodness-of-fit :

$$
\begin{aligned}
\chi^{2} & =\Sigma \frac{(\text { observed catch }- \text { expected catch })^{2}}{\text { expected catch }} \\
& =\frac{(13-13.75)^{2}}{13.75}+\ldots \ldots \ldots \ldots \ldots+\frac{(32-32.71)^{2}}{32.71} \\
& =0.34
\end{aligned}
$$

This $\chi^{2}$ value is referred to a table of the percentage points of the $\chi^{2}$ distribution. Agreement between observed and expected catches is accepted $(\mathrm{P}>0.05)$ if the $\chi^{2}$ value is less than the appropriate $5 \%$ point for $v$ degrees of freedom $(v=n-1)$. Table III gives the $5 \%$ points for 1 to 10 degrees of freedom. As the $\chi^{2}$ value of 0.34 is well below the $5 \%$ point (12.59 for 6 degrees of freedom), there is good agreement between the observed and expected catches. Therefore we accept the hypothesis that the catches in the 7 nels were proportional to the volumes of water sampled by the nets. This result agrees with the hypothesis that the size of the catch increases as the volume of water flowing through a drift sampler increases (see 3.1 ). When drift rate is found to be proportional to the volume of water sampled by a net, it can be assumed that drift density (numbers drifting per unit volume of water) is fairly constant. Variations in drift density are then assumed to be due to random causes, and drift density is treated as a Poisson variable.

TABLE III. $5 \%$ significance levels for $\chi^{2}$ test for goodness-of-fit. Agreement between observed and expected catches is accepted $(P>0.05)$ if $x^{2}$ value is less than stated value, and is rejected $(P<0.05)$ if $x^{2}$ value is greater than stated value. $v=$ number of degrees of freedom $=n-1$

$\begin{array}{rc}\mathbf{v} & \text { significance point } \\ 1 & 3.84 \\ 2 & 5.99 \\ 3 & 7.82 \\ 4 & 9.49 \\ 5 & 11.07 \\ 6 & 12.59 \\ 7 & 14.07 \\ 8 & 15.51 \\ 9 & 16.91 \\ 10 & 18.31\end{array}$


This assumption can be checked by comparing drift density over several days. If the drifting invertebrates are randomly distributed in the water and a constant water volume is sampled on each day, then the drift density should follow a Poisson series. In experiment 2, the 7 nets were left sampling for a further 4 nights and filtered $452 \mathrm{~m}^{3}$ of water on each night. The catches for the 5 nights were $168,150,179,172,166$. These catches were tested for randomness by the $\chi^{2}$ test for agreement with a Poisson series :

$$
\begin{gathered}
\bar{x}=167, s^{2}=115, n=5, \mathrm{v}=4 \\
\chi^{2}=\frac{4(115)}{167}=2.75
\end{gathered}
$$

As this $\chi^{2}$ value lies within the $5 \%$ significance levels for 4 degrees of freedom (Table I), agreement with a Poisson series is accepted $(\mathrm{P}>0.05)$. Therefore the variation in drift density (numbers $/ 452 \mathrm{~m}^{3}$ ) was probably due to random causes and drift density can be treated as a Poisson variable.

\subsubsection{Estimation of total numbers drifting downstream.}

It is important to estimate total drift for the whole cross-section width of a stream so that comparisons can be made between streams, estimates of total drift food for fish can be made, and the effect of drift on benthic populations can be assessed. A good standard measure of total drift is the total numbers drifting downstream per day divided by the total discharge, to give the daily drift rate per unit discharge. As it is rarely possible to catch all the invertebrates drifting though the entire width of a stream, the total drift has to be estimated from drift samples. Therefore we require an estimate of total drift together with some indication of the precision of this estimate.

WATERS [1969] describes a simple method of estimating total drift. The distribution of drift rate across an entire width transect is first found by placing fixed nets (Fig. 1A) across the entire width of a stream. The ratio between the catch in the sample net and the total drift is next found, and it is assumed that this ratio remains constant at least for the experimental period. The sample net is then used to estimate total drift, which is the product of the above ratio and the eatch in the sample net. It is difficult to determine the precision of this estimate and the method assumes that there is a constant ratio of total drift to the catch in the sample net. This assumption must be frequently checked, and this is a laborious procedure, especially in wide streams or rivers. 
The following methods of estimating total drift require some knowledge of the spatial variations in drift rate. Therefore it is important to understand the statistical methods described in 3.4.1. and 3.4.2. The precision of each estimate is best expressed as $95 \%$ confidence limits Confidence limits are usually calculated by multiplying the standard error of the mean by an appropriate value from a table of Student's t-distribution [e.g. PEarson \& Hartley 1966, Table 12]. This method results from the central limit theorem and is applicable to small samples $(\mathbf{n}<30)$ from a Poisson series when to the product $n \bar{x}$ is greater than 30 , but not to small samples from other non-normal populations [see Chapter 6 in Elliot 1970].

Total drift is estimated from mean drift rate when agreement with a Poisson series is accepted for catches at different points across the stream. For example, agreement with a Poisson series was accepted for the night catches in experiment 1 (Table II). Therefore the arithmetic mean of the 7 catches (mean drift rate) was used to estimate total drift. The arithmetic mean and its $95 \%$ confidence limits are given by :

$$
\bar{x} \pm t \sqrt{\frac{\bar{x}}{n}}
$$

where the appropriate value of $t$ is found in published tables of Student's t-distribution.

$$
\begin{gathered}
t=2.45 \text { for } v=n-1=6 \text { degrees of freedom. } \\
\begin{array}{c}
\bar{x} \pm t \sqrt{\frac{\bar{x}}{n}}=64.14 \pm 2.45 \sqrt{\frac{64.14}{7}} \\
=64.14 \pm 7.42
\end{array}
\end{gathered}
$$

This was the best estimate of drift rate for a section $12 \mathrm{~cm}$ wide (width of each net). As the total width of the stream was $204 \mathrm{~cm}$, an estimate of total drift in a night was given by :

$$
(\bar{x}) \frac{204}{12}=(64.14) 17=1090.38
$$

$95 \%$ confidence limits for this estimale were given by :

$$
\left(\mathrm{t} / \frac{\overline{\mathrm{x}}}{\mathrm{n}}\right) \frac{204}{12}=(7.42) 17=126.14
$$

Therefore the total number of nymphs drifting downstream was probably $(\mathrm{P}=0.95)$ between 964 and 1216 in a night, and the best estimate of total drift was $1090 \pm 126$. 
Total drift is estimated from drift density when agreement with a Poisson series is rejected for catches at different points across the stream, but the catches in a series of nets are proportional to the volumes of water sampled by the nets. Drift density is assumed to be a Poisson variable, but this assumption can be checked (see 3.4.2). $95 \%$ confidence limils for Poisson variables are given in published tables (e.g. Crow \& Gardoner 1959), Documenta Geigy: 1962, Pearson \& Hartley 1966], or are approximated by $x-2 \sqrt{x}$ to $x+2 \sqrt{x}$ when $x$ is a Poisson variable $>30$. As confidence limits for a Poisson variable decrease with the size of the count, the largest available count should be used to estimate total drift.

For example, the night catches in experiment 2 varied significantly across the stream, but the catches were proportional to the water volumes sampled by the nets. Therefore drift density was treated as a Poisson variable. The total catch of 168 for the 7 nets was the largest available count, and provided an estimate of total numbers per $452 \mathrm{~m}^{3}$ of water. $95 \%$ confidence limits for this estimate are 144 to 194 from tables [from Crow \& GARDNER 1959], or approximately $x-2 \sqrt{x}$ to $x+2 \sqrt{x}=142$ to 194 or $168 \pm 26$. As total stream discharge for the night was $1088 \mathrm{~m}^{3}$, an estimate of total drift in a night was given by :

$$
\text { (168) } \frac{1088}{452}=404
$$

$95 \%$ confidence limits for this estimate were :

$$
\text { (144) } \frac{1088}{452} \text { to } 194 \frac{(1088)}{452}=347 \text { to } 467
$$

or $404 \pm 63$ for approximate limits.

Therefore the total number of nymphs drifting downstream was probably $(\mathrm{P}=0.95)$ between 347 and 467 in a night, and an estimate of tolal drift was $404 \pm 63$ (with approximate confidence limits).

Total drift can usually be estimated from either drift rate or drift density, using the above methods. Although these methods are suitable for most samples, they cannot be applied to drift samples with very variable calches $\left(x^{2}>\right.$ upper $5 \%$ level in Table I) which are not proportional to water volume passing through the drift sampler. The arithmetic mean of these samples may be biased by extreme values, and a transformation of the data is necessary before confidence limits can be calculated. A description of these more complex statistical methods cannot be included here, but the methods are described in detail by ELLIOTT [1970, Chapter 6.2.4]. 


\section{SUMMARY}

The first part of the paper reviews and criticises drift samplers. The samplers are divided into three broad categories:

1. Samplers without flow-meters (Fig. 1).

2. Samplers with flow-meters (Fig. 2).

3. Tube samplers (Fig. 3) and other more complex samplers.

The second part of the paper considers some problems associated with drift sampling.

As the volume of water flowing through a drift sampler increases, the size of the catch increases. The average relationship between the two variables can be expressed by a regression line (e.g. Fig. 5). A distinction is made between drift rate (the number of invertebrates passing a sampling point in unit time) and drift density (the number of invertebrates per unit volume of water). The relationship between drift rate and drift density is discussed. A summary is given of all the factors which affect drift density.

The sampling efficiency of drift samplers is discussed, and the results of efficiency tests are described. As the performance and sampling efficiency of a lrift sampler vary with local stream conditions, they must be thoroughly tested before the start of regular drift sampling.

The study of the diel periodicity in invertebrate drift is discussed. The diel drift pattern greatly varies when different sampling periods are used (Fig. 6).

The following statistical problems are discussed :

1. Temporal and spatial variations in drift rate and drift density, using Poisson series as a statistical model.

2. The estimation of total numbers drifting downstream. Total drift is estimated from drift rate when agreement with a Poisson series is accepted for samples across the stream. Total drift is estimated from drift density when agreement with a Poisson series is rejected, and the catches in a series of nets are proportional to the volumes of water sampled by the nets.

\section{LES Methodes D'ETUde De LA DERIVE DES INVERTEBRés DANS LES COURS D'EAU}

La première partie de cet article concerne la critique des pièges à dérive. Trois catégories sont distinguées :

1. Les pièges sans débitmètre (fig. 1),

2. Les pièges avec débitmètre (fig. 2),

3. Les tubes avec évacuation d'eau (fig. 3) et autres pièges plus complexes.

La deuxième partie concerne les divers problèmes associés à l'étude le la dérive des invertébrés.

L'échantillon est d'autant plus important que le volume d'eau s'écoulant au travers du piège est plus élevé. Le rapport moven entre ces 
deux variables est exprimé par une ligne de régression (par exemple fig. 5). Il importe de distinguer le taux de dérive (nombre d'invertébrés passant en un point de repère par unité de temps) et la densité de dérive (nombre d'invertébrés par unité de volume d'eau). Les rapports entre le taux et la densité de dérive sont discutés. Les facteurs influençant la densité de dérive sont résumés.

L'efficacité des pièges à dérive est discutée à la lumière des résultats obtenus par les auteurs. Le fonctionnement des pièges variant avec les conditions de chaque cours d'eau, leur efficacité doit être testée avant l'échantillonnage des invertébrés en dérive.

L'étude du rythme nycthéméral de la dérive des invertébrés est discutée. La forme des histogrammes est grandement influencée par la fréquence de l'échantillonnage (fig. 6).

Les problèmes statistiques suivants sont discutés :

1. Les variations dans le temps et dans l'espace de la dérive (taux et densité) en utilisant la série de Poisson comme modèle.

2. L'estimation des nombres totaux de dérive. La dérive totale est évaluée à partir du taux de dérive quand l'échantillonnage s'accorde avec la série de Poisson. La dérive totale est évaluée à partir de la densité de la dérive quand l'échantillonnage ne s'accorde pas avec la série de Poisson et est proportionnel au volume d'eau traversant les filets.

\section{METHODEN DER SAMMLUNG VON INVERTEBRATENDRIFT IN FLIESSGEWÄSSERN}

Im ersten Teil der Arbeit werden Driftsammler aufgeführt und kritisch betrachtet. Die Sammler sind in drei Grundkategorien eingeteilt :

1. Sammler ohne Strommesser (Abb. 1).

2. Sammler mit Strommesser ( $A b b, 2)$.

3. Rohrsainmler $(A b b .3)$ und andere Komplexere Sammler.

Im zweiten Teil der Arbeit werden einige Probleme in Zusammenhang mit dem Driftsammeln behandelt.

Wenn die Wassermenge, die durch einen Driftsammler fliesst, wächst, nimmt auch die Grösse des Fanges zu. Das durchschnittliche Verhältnis der beiden Variabeln kann durch eine Rückkehrlinie ausgedrückt werden (z. B. $A b b$. 5). Man unterscheidet zwischen Verhältnis der Drift (Die Zahl der Invertebraten, die einen Sammlerpunkt in einer Zeiteinheit passieren) und Dichte der Drift (die Zahl der Invertebraten pro Wassermengeneinheit). Die Relation zwischen Verhältnis der Drift und Dichte der Drift wird besprochen. Es folgt eine zusammenfassung aller Faktoren, die die Dichte der Drift beeinflussen .

Die Effizienz der Driftsammler wird besprochen, und die Ergebnisse der Effizienztests werden beschrieben. Da die Arbeit und Effizienz der Driftsammler sich mit dem örtlichen Wasserzustand ändern, müssen sie vor dem Beginn des regelmässigen Driftsammelns gründlich geprüft werden. 
Dic Untersuchung der Dielperiodizität der Invertebratendrift wird besprochen. Das Schema der Dieldrift variiert erheblich, wenn verschiedene Sammelnperioden gewählt werden $(A b b .6)$.

Die folgenden statistischen Probleme werden besprochen :

1. Zeitliche und räumliche Verteilung in Verhältnis der Drift und Dichte der Drift, unter Anwendung einer Poisson Serie als statistisches Muster.

2. Schätzung der Gesamtzahl von Driften Stromabwärts. Die Gesamtdrift wird von Verhältnis der Drift berechnct, wenn Übereinstimmung mit einer Poisson Serie angenommen wird für Samples quer über das Gewässer. Die Gesamtdrift wird von der Dichte der Drift berechnet, wenn Übereinstimmung mit einer Poisson Serie nicht angenommen wird, und der Fang in einer Feihe von Netzen proportional der Wassermengen ist, die von den Netzen als Samples genommen wurden.

\section{REFERENCES}

Anderson (N.H.). 1967. - Biology and downstream drift of some Oregon Trichoptera. Can. Ent., 99 : 507-521.

Anderson (N.H.) \& LeHMKUHL (D.M.) 1968. - Catastrophic drift of insects in a woodland stream. Ecology, $49: 198-206$.

BAILEY (R.G.). 1966. - Observations on the nature and importance of organic drift in a Devon river. Hydrobiologia, 27: 353-367.

Besch (W.). 1966. - Driftnetzmethode und biologische Fliesswassersuntersuchung. Verh. int. Verein. theor. angew. Limnol., 16 : 669-677.

Bishop (J.E.) \& Hynes (H.B.N.). 1969. - Downstream drift of the invertebrate fauna in a stream ecosystem. Arch. Hydrobiol,, 66 : $56--90$.

Chaston (I.). 1968. - Endogenous activity as a factor in invertebrate drift. Arch. Hydrobiol., 64 : 324-334.

CRISP (D.T.). 1966. - Input and output of minerals for an area of Pennine moorland : the importance of precipitation, drainage, peat erosion and animals. J. appl. Ecol., 3 : 327-348.

Crow (E.L.) \& GiRdner (R.S.). 1959. - Table of confidence limits for the expectation of a Poisson variable. Biometrika, $46: 441-453$.

Cushing (C.E.). 1964. - An apparatus for sampling drifting organisms in streams, J. Wildl. Mgmt., 28 : 592-594.

DeNDY (J.S.). 1944. - The fate of animals in stream drift when carried into lakes. Ecol. Monogr., 14 : 333-357.

Dennert (H.G.), Dennert (A.L.), Kant (P.), Pinkster (S.) \& Stock (J.H.). 1969. - Upstream and downstream migrations in relation to the reproductive cycle and to environmental factors in the Amphipod, Gammarus zaddachi. Bijdr. Dierk., 39 : 11-43.

Dimond (J.B.). 1967. - Evidence that drift of stream benthos is density related. Ecology, $48: 855-857$.

Documenta Geigy. 1962. - Scientific Tables. 6th. edition (ed. by K. DIEM), pp. 778.

Elliott (J.M.). 1967a. - Invertebrate drift in a Dartmoor stream. Arch. Hydrobiol., 63 : 202-237.

Eumrote (J.M.). 1967b. - The life histories and drifting of the Plecoptera and Ephemeroptera in a Dartmoor stream. J. Anim. Ecol., 36 : $343-362$. 
Eldiott (J.M.). 1968a. - The life histories and drifting of Trichoptera in a Dartmoor stream. J. Anim. Ecol., 37: 615-625.

ErLiot (J.M.). 1968b. - The daily activity patterns of mayfly nymphs (Ephemeroptera). J. Zool., 155: 201-221.

Elliott (J.M.). 1969. - Diel periodicity in invertebrate drift and the effect of different sampling periods. Oikos. 20 : 524-528.

Elliotr (J.M.). 1970. - Some methods for the statistical analysis of samples of benthic invertebrates. Scient. Publs. Freshwat. biol. Ass., 26 : (in press).

Elliot (J.M.) et Minshall (G.W.). 1968. - The invertebrate drift in the River Duddon, English Lake District. Oikos, 19 : 39-52.

H.trdy (C.J.). 1968. - Freshwater fisheries field techniques: drift sampling. Fisheries Technical Report. No. 27. Wellington, New Zealand.

Kubicek (F.). 1966. - Eine neue Methode der quantitiven Entnahme der organischen Drift. Zool. Listy, 15 : 284-286.

KunEck (A.). 1967. - Uber die tagesperiodische Ausdrift von Niphargus aquilex Schellenbergi Karaman aus Quellen. Z. Morph. Okol. Tiere, 58 : 247-262.

L.ennon (R.E.). 1941. - Drift borne organisms in Pond Brook, Passaconaway N. H. Univ. N. H. Extension Ser., Contrib. 2, Biol. Inst., $14 \mathrm{pp}$.

Lyakhov (S.M.) \& $Z$ Hinkov (L.F.). 1953. A bottom trap - an apparatus for studying benthic organisms carried down by the river current (in Russian). Zool. Zh. Ukr., 32 : 1020-1024.

McLAy (C.L.). 1968. - A study of drift in the Kakanui River, New Zealand. Aust. J, mar. Freshwat. Res., 19 : 139-149.

Minshall (G.W.) \& Winger (P.V.). 1968. - The effect of reduction in stream flow in invertebrate drift. Ecology, $49: 580-582$.

Mülder (K.). 1954. - Investigations on the organic drift in North Swedish streams, Rep. Inst. Freshwat. Res. Drottningholm, 35 : 133-148.

MüLLER (K.). 1958. — Beitrag zur Methodik der Untersuchung fliessender Gewässer. Arch. Hydrobiol., 54 : 567-570.

MüLLeR (K.). 1963. - Tag - Nachtrhythmus von Beatidenlarven in rler organischen Drift. Naturwissenschaaften, 50 : 1-3.

MülLER (K.), 1965, - An automatic stream irift sampler. Limnol. Oceanogr., 10 : 483-485.

MülLER (K.). 1966. - Die Tagesperiodik von Fliesswasserorganismen. Z. Morph. Okol. Tiere, 56 : 93-142.

Mundie (J.H.). 1964. - A sampler for catching emerging insects and drifting materials in streams. Limnol. Oceanogr., 9: 456-459.

Mundie (J.H.) . 1966. - Sampling emerging insects and drifting materials in deep flowing water. Gewass. Abwass., 41/42 : 159-162.

Needham (P.R.). 1928. - Net for capture of stream drift organisms. Ecology, 9 : 339-342.

Pearson (E.S.) \& Hartley (H.O.). 1966. - Biometrika tables for satisticians. (3rd edition) Cambridge University Press, pp. 264.

Piarson (W.D.) \& Franklis (D.R.). 1968. - Some factors affecting drift rates of Baetis and Simuliidae in a large river. Ecology, 49 : $75-81$.

Pearson (W.D.) \& Krammer (R.H.). 1969. - A drift sampler driven by a water-wheel. Limnol. Oceanogr., 14: 462-465. 
TANAKa (H.). 1960. - On the daily change of the drifting of benthic animals in a stream, especially on the types of daily change observed in taxonomic groups of insects. Bull. Freshwat. Fish. Res. Lab. Tokyo, 9: 13-24.

Ulfstrand (S.). 1968. - Benthic animal communities in Lapland streams. Oikos, Suppl., 10 : 1-120.

WATERS (T.F.). 1961. - Standing crop and drift of stream bottom organisms. Ecology, 42 : 532-537.

Waters (T.F.). 1962. - Diurnal periodicity in the drift of stream invertebrates. Ecology, 43 : 316-320.

WATERS (T.F.). 1965). - Interpretation of invertebrate drift in streams. Ecology, 46: 327-334.

Waters (T.F.). 1966. - Production rate, population density, and drift of a stream invertebrate. Ecology, 47: 595-604.

WATERS (T.F.). 1969. - Invertebrate drift - ecology and significance to stream fishes. In Symposium on salmon and trout in streams, 121-134. Vancouver. Univ. B.C.

Welsh (P.S.). 1948. - Limnological Methods. Philadelphia, 381 pp.

WolF (P.). 1951. - A trap for the capture of fish and other organisms moving downstream. Trans. Am. Fish. Soc., 80 : 41-45.

(Freshwater Biological Association, Ambleside, Westmorland, England.) 